\title{
Psicopatología de pacientes dependientes de cocaína en una comunidad terapéutica
}

\section{Psychopathology of cocaine dependent patients in a therapeutic community}

\author{
Ricardo Tavares Pinheiro*; Pedro Vieira da Silva Magalhaes**; Andrea Veiga Wagner***; \\ Karen Amaral Tavares Pinheiro*; Ricardo Azevedo da Silva*; luciano Dias Mattos Souza* \\ * Licenciado en Salúd y Comportamiento, Universidad Católica de Pelotas, Brasil. \\ **Facultad de Medicina y Facultad de Psicología. Universidad Católica de Pelotas, Brasil. \\ ***Facultad de Psicología. Universidad Católica de Pelotas, Brasil. \\ Enviar correspondencia a/Correspondence to: \\ Pedro Vieira da Silva Magalhaes. Licenciado en Salúd y Comportamiento, Universidad Católica de Pelotas. \\ Rúa Almirante Barroso n.1202, bloco G.109. Pelotas - RS - Brasil CEP: 96010-280. \\ Teléfono: 5553 99832271. E-mail: maga@ufpel.tche.br
}

\section{RESUMEN}

Objetivo y métodos: Pacientes varones de una comunidad terapéutica (102 individuos) de una ciudad del sur de Brasil, con un diagnóstico primario de dependencia de cocaína, que fueron evaluados con el Sistema exhaustivo de Exner para el Rorschach con el fin de describir la psicopatología de la personalidad. Resultados: Presencia de lambdas altos en el $62 \%$ de los pacientes. El 60,8\% de los pacientes dieron positivo en el índice de déficit de recursos (CDI) y el 22,5\% en el índice de depresión. Se observó menor presencia de otras constelaciones (<5\%). Conclusiones: Un CDI positivo, la medición de la resolución de dificultades y de la falta de habilidades sociales, incide en el éxito del tratamiento, como en el caso de la selección de intervenciones para corregir dificultades interpersonales. Por tanto, en estos pacientes debe hacerse una valoración de la personalidad.

Palabras clave: trastornos relacionados con la cocaína, habilidades sociales, psicopatología, comunidad terapéutica, test de Rorschach, Brasil.

\section{ABSTRACT}

Objective and methods: Male patients in a therapeutic community $(n=102)$ from a city in southern Brazil, with a primary diagnosis of cocaine dependence, were evaluated with Exner's Comprehensive System for the Rorschach, with the objective of describing personality psychopathology. Results: High lambdas were present in $62 \%$ of patients. $60.8 \%$ of the patients scored positive in the Coping Deficit Index; $22.5 \%$ in the Depression Index. Other constellations were infrequently present $(<5 \%)$. Conclusions: A positive CDI, a measure of difficulty in the management of complexities and poor social skills, may have treatment-matching implications, such as the selection of interventions targeted at interpersonal difficulties. Personality assessment should be considered in such patients.

Key words: cocaine-related disorders, coping skills, psychopathology, therapeutic community, Rorschach test, Brazil.

\section{INTRODUCCIÓN}

i bien la drogodependencia ha de ubicarse en un contexto que no se limite a los rasgos de la personalidad, los individuos que sufren trastornos por consumo de sustancias presentan diferencias en los controles de varias dimensiones de la personalidad (Franques, Auriacombe y Tignol, 2000). Una sola valoración no proporciona una imagen completa de la

\section{INTRODUCTION}

W hile drug dependence should be viewed in a broader context than personality features, individuals with substance use disorders are different from controls on several dimensions of personality (Franques, Auriacombe \& Tignol, 2000). Although no single assessment is sufficiently comprehensive to provide a complete picture of 
personalidad. El Sistema Comprensivo de Exner (CS) da solidez al test de Rorschach desde el punto de vista psicométrico (Vincent y Harman, 1991). El CS evalúa críticamente la utilidad del Rorschach y le da una interpretación más objetiva y fiable. La validación del CS se realizó a través del examen de gran número de controles normativos en diferentes culturas, lo cual permite el análisis cuantitativo de la psicopatología (Exner, 2003).

En tres estudios Rorschach previos sobre la psicopatología de los pacientes dependientes de cocaína, que no utilizaron el CS, las muestras presentaron elevados niveles de narcisismo, ira y negatividad y dificultaron la comparación con la realidad (Dougherty y Lesswing, 1989; Lesswing y Dougherty, 1993; Pinheiro, Sousa, Silva, Horta, Souza y Fleming, 2001). En un estudio que utilizó el CS para evaluar a sesenta mujeres consumidoras de alcohol (Bergman, Haver, Bergman, Dahlgren y Nielsen, 1998), las pacientes manifestaron una psicopatología mucho más significativa que el grupo comparativo de mujeres no pacientes de Exner y, en cambio, presentaron similitudes con el modelo de pacientes deprimidos de Exner.

En esta serie utilizamos el CS con el fin de describir la psicopatología de los pacientes hospitalarios dependientes de cocaína. Puesto que la patología de la personalidad se considera un importante factor de riesgo de dependencia de sustancias (Verheul y Van den Brink, 2000), hemos hecho especial hincapié en las seis constelaciones psicopatológicas descritas en el CS.

\section{MÉTODO}

\section{Participantes}

Se incluyeron todos pacientes de una comunidad terapéutica con un diagnóstico primario de dependencia de cocaína según los criterios del DSM-IV entre 1998 y 2000 . Se excluyeron los pacientes consumidores de sustancias adicionales que entraban bajo los criterios de dependencia, y también los que presentaban síntomas psicóticos manifiestos. El psicólogo encargado de las admisiones estableció el diagnóstico en las instalaciones destinadas a la seleccción. Todos los pacientes dieron su consentimiento escrito.

La comunidad terapéutica, localizada en una zona rural de Pelotas, una ciudad del sur del Brasil con una población aproximada de trescientas mil personas, trató a pacientes varones con trastornos derivados del consumo de sustancias durante un período fijo de nueve meses tras un período de abstinencia de treinta días. personality, Exner's Comprehensive System (CS) is viewed as making the Rorschach psychometrically sound (Vincent \& Harman, 1991). The CS is an effort to critically evaluate the usefulness of the Rorschach and give it a more objective and reliable interpretation. Validation of the CS was conducted through examination of large numbers of normative controls in different cultures, which allows for quantitative analysis of psychopathology (Exner, 2003)

In three previous Rorschach studies of psychopathology in cocaine dependent patients, which did not use the CS, the samples displayed high levels of narcissism, anger and negativity, and reduced reality testing (Dougherty \& Lesswing, 1989; Lesswing \& Dougherty, 1993; Pinheiro, Sousa, Silva, Horta, Souza \& Fleming, 2001). In one study that used the CS to evaluate 60 women who misused alcohol (Bergman, Haver, Bergman, Dahlgren \& Nielsen, 1998), patients displayed significantly more psychopathology than Exner's comparison group of female non-patients and were similar to Exner's depressed sample.

In this case series, we employed the CS with the objective of describing the psychopathology of cocaine dependent inpatients. As personality pathology is thought to be an important risk factor for substance dependence (Verheul \& van den Brink, 2000), we had special interest in the six psychopathological constellations described in the CS.

\section{METHOD}

\section{Participants}

Every patient admitted to a therapeutic community, between 1998 and 2000, with a primary diagnosis of cocaine dependence according to DSM-IV criteria, was included. Patients with additional substance use, severe enough to meet dependence criteria, were excluded, as were those with overt psychotic symptoms. The admitting psychologist established the diagnosis in the community's triage facility. All patients provided written informed consent for participation.

The therapeutic community, located in a rural area in Pelotas, a city located in southern Brazil with a population of approximately 300.000 people, treats male patients with substance related disorders for a fixed 9-month period, after a 30-day period of abstinence. 


\section{Procedimiento}

Se utilizaron entrevistas clínicas semidirigidas y tests de Rorschach en la tercera y cuarta semanas; los pacientes guardaron abstinencia durante al menos siete semanas.

Las constelaciones se clasificaron en dos grupos, tal y como describe Exner (2003). Se consideró que el índice de depresión (DEPI) era positivo cuando superaba el 4, el índice de déficit de recursos (CDI) cuando superaba el 3, el índice de pensamiento perceptual (PTI) cuando superaba el 2, la constelación de suicidio (S-CON) cuando superaba el 8, el índice de estilo obsesivo (OBS) cuando se daba alguna de las condiciones de Exner, y el índice de hipervigilancia (HVI) cuando se daba la primera condición y otras cuatro condiciones adicionales.

Otro psicólogo que desconocía la primera valoración realizó treinta tests de Rorschach al azar. Los examinadores eran psicólogos clínicos de nivel especializado pertenecientes a la Asociación Brasileña de Investigación Rorschach.

Aunque existe un "modelo normativo» para la población brasileña (Nascimento, 2002), no nos parece fiable. En primer lugar, el modelo normativo se compone principalmente de voluntarios y la autoselección conduce a la parcialidad. En segundo lugar, el número medio de respuestas (R) del modelo fue bajo $(R=18)$, lo cual infló los índice psicopatológicos (por ejemplo, el 21\% de los sujetos dieron positivo en el índice de esquizofrenia). En tercer lugar, aunque la autora reconoce que $\mathrm{R}$ es un factor de confusión, no corrige los índices. Creemos que sigue siendo necesario un modelo normativo y representativo para Brasil. Y por ello, hemos comparado los resultados de nuestro modelo con los del nuevo modelo de Exner (2002), y también con un modelo de voluntarios; se ha optado por este nuevo modelo para corregir algunas limitaciones de los datos normativos previos. Los voluntarios procedían de organizaciones y empresas de catorce Estados de Estados Unidos, y la cuarta parte de los protocolos se repitieron para garantizar la precisión.

\section{Análisis}

Los análisis se realizaron con el paquete estadístico SPSS para Windows 10.1. Para comparar promedios, se utilizaron pruebas t de Student de dos colas, y para comparar proporciones el test de probabilidad exacta de Fischer.

\section{Procedure}

Clinical semi-directed interviews and Rorschach assessments were applied through the third and fourth weeks. Patients were, thus, necessarily abstinent for at least 7 weeks.

The constellations were dichotomized as described by Exner (2003). Briefly, the Depression Index (DEPI) was considered positive when higher than 4, the Coping Deficit Index (CDI) when higher than 3, the Perceptual Thinking Index (PTI) was considered positive when higher than 2 , the Suicide Constellation (S-CON) when higher than 8, the Obsessive Style Index (OBS) when any one of Exner's conditions were true and the Hypervigilance Index (HVI) when the first condition was true and 4 of the additional conditions also were true.

Thirty Rorschach tests were randomly re-scored by another psychologist blind to the first assessment. Examiners were master's level clinical psychologists trained by the Brazilian Association for Rorschach Research.

Although a "normative sample" for the Brazilian population is available (Nascimento, 2002), we believe that sample to be unreliable. Firstly, the normative sample was mostly comprised of volunteers; self-selection is prone to bias. Secondly, the median number of responses $(R)$ for that sample was low $(R=18)$, possibly inflating psychopathological indices (e.g. $21 \%$ of subjects were positive for the Schizophrenia Index). Third, although the author recognizes that $R$ is a confounder, she does not provide corrections for the indices. We believe a representative normative Brazilian sample is still needed. Because of this, we have compared results in our sample with those of Exner's new sample (2002), although also a volunteer sample; this new sample has been collected in an attempt to address some limitations of the previous normative data. In brief, volunteers were recruited from organizations and businesses in 14 states from the USA; onefourth of protocols were re-scored to check for accuracy.

\section{Analysis}

All analysis were made using SPSS for Windows 10.1. To compare means, two-tailed Student's t tests were employed and Fisher's exact test was used to compare proportions. 


\section{RESULTADOS}

En el estudio participaron ciento dos pacientes. La edad media era de veintiún años $(80 \%$ del rango central entre 16 y 32); cuarenta y cuatro pacientes tenían menos de veintiún años. La mayoría (74\%) habían estudiado menos de nueve años. Los sujetos dieron una media de veintiséis respuestas $(80 \%$ del rango central entre 15 y 47) y el lambda medio fue de 1.33 ( $80 \%$ del rango central entre 0.44 y 3.10$)$. Los tests repetidos ofrecieron niveles kappa de 0.87 en el DEPI y el CDI, de 0.94 en el S-CON, el 0.84 en el PTI y un nivel kappa del 0.67 en el HVI y el OBS.

Más de la mitad de los pacientes (60.8\%) entraban en el rango patológico del CDI. Veintitrés (22.5\%) entraban en el rango patológico del DEPI. Las otras tres constelaciones apenas aparecieron (menos del $4 \%$; ver tabla 1). La edad no se asociaba con ningún índice, ni de forma continua ni partiendo de los veintiún años (datos que no se muestran). Los pacientes con protocolos más largos tenían mayor tendencia a dar positivo en el DEPI ( $p<0.05)$, sin alteraciones en otras variables (datos que no se muestran).

Sesenta y tres individuos tenían un lambda alto $(>0.99)$, que no se asociaba con un CDI positivo ni con ningún otro índice ( $p>0.05$ en conjunto).

En comparación con el modelo normativo de Exner (2002), el número medio de respuestas era mucho mayor en estos pacientes ( $t=4.81, p<0.001)$, al igual que el lambda $(t=5.35, p<0.001)$ y la frecuencia del CDI $(p<0.001)$ (Tabla 1).

\section{RESULTS}

One hundred and two patients were included in the study. Median age was 21 (80\% central range 16-32); forty-four patients were younger than 21. A majority $(74 \%)$ had less than 9 years of education. Subjects gave a median of 26 answers $180 \%$ central range 15-47) and the median lambda was 1.33 (80\% central range 0.44-3.10). The re-scored tests yielded kappa levels of 0.87 for the DEPI and for the CDI, 0.94 for the S-CON, 0.84 and for the PTI and a kappa level of 0.67 for the $\mathrm{HVI}$ and the OBS.

More than half $(60.8 \%)$ of the patients scored in the pathological range of the CDI. Twenty-three $(22.5 \%)$ patients scored in the pathological range of the DEPI. The other three constellations were infrequently present (in less than 4\%; see Table 1). Age was not associated with any of the indices, either continuously or split at age 21 (data not shown). Patients with longer protocols were more likely to be positive only for the DEPI $(p<0.05)$, not affecting other variables (data not shown).

Sixty-three individuals had a high lambda (>0.99), which was not associated with a positive CDI or with any other indices ( $p>0.05$ for all).

When compared to Exner's normative sample (2002), these patients show a significantly higher mean number of responses $(t=4.81, p<0.001)$, Lambda $(t=5.35, p<0.001)$ and frequency of the CDI $(p<0.001)$ (table 1).

Tabla 1: Índices psicopatológicos en el modelo de estudio y en un modelo normativo

Table 1: Psychopathological indices in the study sample and in a normative sample (Exner, 2002)

\begin{tabular}{|c|c|c|}
\hline & $\begin{array}{l}\text { Pacientes dependientes de cocaína ( } n=102) \\
\text { Cocaine dependent patients }(n=102)\end{array}$ & $\begin{array}{l}\text { Nuevo modelo normativo de Exner }(n=175) \\
\text { Exner's new normative sample }(n=175)\end{array}$ \\
\hline $\begin{array}{l}\text { Número medio de respuestas (SD) } \\
\text { Mean number of responses (SD) }\end{array}$ & $28.04(11.9)^{*}$ & $22.98(5.51)$ \\
\hline $\begin{array}{l}\text { Lambda medio (SD) } \\
\text { Mean lambda (SD) }\end{array}$ & $1.12(1.61)^{*}$ & $0.61(0.38)$ \\
\hline $\begin{array}{l}\text { DEPI positivo (\%) } \\
\text { Positive DEPI (\%) } \\
\text { DEPI }=5 \\
\text { DEPI }=6 \\
\text { DEPI }=7\end{array}$ & $\begin{array}{c}22.5 \\
19.6 \\
2.9 \\
0\end{array}$ & $\begin{array}{c}16 \\
12.6 \\
2.9 \\
0.6\end{array}$ \\
\hline $\begin{array}{l}\text { PTI positivo (\%) } \\
\text { Positive PTI (\%) }\end{array}$ & 2.9 & 0.6 \\
\hline $\begin{array}{l}\text { CDI positivo (\%) } \\
\text { Positive CDI (\%) }\end{array}$ & $60.8^{*}$ & 6.3 \\
\hline $\begin{array}{l}\text { HVI positivo (\%) } \\
\text { Positive HVI (\%) }\end{array}$ & 3.9 & 5.7 \\
\hline $\begin{array}{l}\text { OBS positivo (\%) } \\
\text { Positive OBS (\%) }\end{array}$ & 2.0 & 1.1 \\
\hline $\begin{array}{l}\text { S-CON positivo (\%) } \\
\text { Positive S-CON (\%) }\end{array}$ & 1.0 & 0 \\
\hline
\end{tabular}

${ }^{*} p<0.0001$ para la diferencia entre medias. ${ }^{*} p<0.0001$ for difference between means 


\section{DISCUSIÓN}

El hallazgo más notable del presente estudio es la alta proporción de pacientes que entran en el rango patológico del CDI en comparación con un modelo de referencia (Exner, 2002). Exner y Sendin (1998) interpretaron originariamente el CDI como indicador de dificultades interpersonales, es decir, una medición de la incapacidad para afrontar complicaciones y de la falta de habilidades sociales. Exner observó luego que un CDI positivo indicaba una dificultad de relación que se podía corregir con una terapia bien planeada y que la recuperación no dependía de los fundamentos teóricos del terapeuta. Como ningún agente farmacológico específico ha resultado efectivo (Lima, Soares, Reisser y Farrell, 2002), suscitan interés los enfoques conductuales de la dependencia de la cocaína, si bien la investigación en este campo está aún en sus inicios (Carroll, 1997).

Hemos de subrayar que encontramos una alta proporción de pacientes con lambdas elevados. Aunque Exner (2003) alertó de la posibilidad de actitudes defensivas, el notable número de respuestas de estos pacientes las descartan. En contra de la hipótesis de Exner nuestros pacientes con un lambda elevado no presentan mayor tendencia a ser positivos en el CDI, sin embargo no podemos descartar que en un estudio más amplio aparezcan asociaciones significativas. Si los lambdas elevados indican un carácter evitativo, con tendencia a eludir la dificultad y a la ambigüedad, nuestros resultados apoyan la propuesta de Campbell (2003) de que los adictos sufren problemas cognitivos: al evitar la dificultad (por ejemplo, negando los recuerdos de acontecimientos negativos), la conducta adictiva se basa en un razonamiento defectuoso. A la vista de estos hallazgos, entendemos que "la valoración rutinaria de los rasgos de la personalidad de los individuos admitidos en tratamiento para corregir el consumo de sustancias debería figurar entre los procedimientos de diagnóstico estándar... pues dicho conocimiento puede tener consecuencias que faciliten el tratamiento» (Verheul y Van den Brink, 2000).

Aunque el DEPI apareció en casi la cuarta parte de la población de nuestro estudio, hay que interpretarlo con cautela, pues su validez y utilidad se han criticado (Meyer y Archer, 2001). En cuanto a los otros cuatro índices, no se pueden hacer deducciones, ya que su presencia es muy escasa en este estudio.

El hecho de que hayamos estudiado sólo a pacientes varones es una limitación que dificulta la extrapolación a otros grupos. Por ejemplo, los hombres presentan modelos de comorbilidad diferentes a las mujeres (Zilberman, Tavares, Blume y el-Guebaly, 2003), lo cual hace que sea muy complicada la com-

\section{DISCUSSION}

The most remarkable finding of the present study is the high proportion of patients scoring in the pathological range of the CDI when compared to a reference sample (Exner, 2002). Exner \& Sendín (1998) originally conceived the CDI as a marker of interpersonal difficulties, which represents a measure of difficulty in the management of complexities and poor social skills. Exner further proposed that a positive CDI indicates a relational inability that could be corrected via well-planned therapy, and recovery should be independent on the theoretical foundations of the therapist. As no specific pharmacological agent has proven to be effective (Lima, Soares, Reisser \& Farrell, 2002), there is interest in behavioural approaches to cocaine dependence, albeit research on this field is in its earliest stages (Carroll, 1997).

Also of interest, we found a high proportion of patients had high Lambdas. Although Exner (2003) has alerted to the possibility of defensiveness, the high number of responses these patients gave render this unlikely. Although, contrary to Exner's hypothesis, our patients with a high Lambda were not more likely to be CDI positive, we cannot rule out that a larger sample could reveal meaningful associations. If high Lambdas indeed represent an avoidant style, used to avoid complexity and ambiguity, then our results support Campbell's (2003) proposition that addicts are cognitively impaired: avoiding complexity (e.g. denying memories of negative events), addictive behaviour is allowed to be based on faulty reasoning. In view of these findings, we agree that "routine assessment of personality traits in individuals admitted for substance abuse treatment should be among the standard diagnostic procedures... such knowledge might have treatment-matching implications" (Verheul \& van den Brink, 2000).

Although the DEPI was present in almost one quarter of our study population, this should be viewed with caution, as its validity and utility have been criticized (Meyer \& Archer, 2001). As for the other four indices, hardly any inference can be made, as their frequency was very low in this sample.

The fact that we studied only male inpatients is a limitation that makes extrapolations to other groups difficult. Men, for example, have different patterns of comorbidities from women (Zillberman, Tavares, Blume \& el-Guebaly, 2003) and this makes the comparison with the findings of Bergman et al. (1998) regarding alcohol abusing women extremely difficult, since it is possible that the differences in psychopathology between these two studies 
paración con los hallazgos de Berman et al. (1998) sobre las mujeres consumidoras de alcohol, pues cabe la posibilidad de que las diferencias psicopatológicas entre los dos estudios se deban simplemente al género. Los pacientes que solicitan tratamiento presentan también niveles de comorbidad y psicopatología más elevados que los consumidores de cocaína dentro de la comunidad (Ochoa, 2000). Para extrapolar estos hallazgos a todos los consumidores de cocaína, necesitaríamos un estudio basado en la población. La falta de controles locales es otra limitación importante. Como no se ha podido controlar la distorsión, debe tenerse en cuenta la posibilidad de que la asociación entre dependencia de cocaína y CDI tenga relación con una variable inconmensurable.

La validez interna del presente estudio tiene gran solidez. Cuando todos los tests de Rorschach sean interpretados y analizados por psicólogos con experiencia y los tests reinterpretados ofrezcan niveles kappa sustanciales, se verá que los resultados que aquí presentamos reflejan la psicopatología de los pacientes varones jóvenes dependientes de la cocaína. De igual forma, aunque la dependencia de la cocaína se relaciona con déficits neuropsicológicos (Cunha, Nicastri, Gomes, Moino y Peluso, 2004), cuando los pacientes se abstuvieron de consumirla durante un período de tiempo significativo, el consumo habitual de drogas quedó eliminado como elemento de distorsión. Desde el punto de vista clínico, estos pacientes presentan psicopatologías concretas y, por tanto, habría que hacer una valoración de su personalidad.

\section{REFERENCIAS / REFERENCES}

Bergman, I., Haver B., Bergman, H., Dahlgren L. y Nielsen, G. H. (1998). Personality characteristics of women with alcohol addiction: a Rorschach study of women in an early treatment programme. Scandinavian Journal of Psychology, 39, 47-54.

Campbell, W. G. (2003). Addiction: a disease of volition caused by a cognitive impairment. Canadian Journal of Psychiatry, 48, 669-674.

Carroll, K. M. (1997). Integrating psychotherapy and pharmacotherapy to improve drug abuse outcomes. Addictive behaviors, 22, 233-245.

Cunha, P.J., Nicastri, S., Gomes, L.P., Moino, R.M. y Peluso, M.A. (2004). Neuropsychological impairments in crack cocaine-dependent inpatients: preliminary findings. Revista Brasileira de Psiquiatria, 26, 103-6.

Dougherty, R. J. y Lesswing, N. J. (1989). Inpatient cocaine abusers: an analysis of psychological and demographic variables. Journal of Substance Abuse Treatment, 6, 45-47. may simply be due to gender. Patients requesting treatment also have higher levels of comorbidity and psychopathology than cocaine abusers in the community (Ochoa, 2000). To extrapolate these findings to all people that misuse cocaine, a population-based sample would be needed. The lack of local controls is another important limitation; as control for confounding was not possible, the likelihood that the association of cocaine dependence with the CDI is in fact related to an unmeasured variable should be bear in mind.

The internal validity of the present study is a major strength. As all Rorschach tests were interpreted and scored by the same experienced psychologist and substantial kappa levels were generated from the re-scored tests, we believe that the results presented herein should be viewed as reflecting the psychopathology of young, male cocaine dependent patients. Also, even if cocaine dependence is related to neuropsychological deficits (Cunha, Nicastri, Gomes, Moino \& Peluso, 2004), as patients were abstinent for a substantial period of time, current drug abuse was eliminated as a confounder. Clinically, as these patients possibly have distinctive psychopathology, personality assessment should be considered.

Exner, J. E. y Sendín, C. (1998). Manual de interpretación del Rorschach. Madrid: Editorial Psimática.

Exner, J. E. (2002). A new nonpatient sample for the Rorschach Comprehensive System: a progress report. Journal of Personality Assessment, 78, 391-404.

Exner, J. E. (2003). The Rorschach: a comprehensive system. Fourth Edition. New Jersey, USA: John Wiley \& sons.

Franques, P., Auriacombe M. y Tignol, J. (2000). Personalités du toxicomane. L'Encephale, 26, 68-78.

Lesswing N. J. y Dougherty R. J. (1993). Psychopathology in alcohol - and cocaine - dependent patients: a comparison of findings from psychological testing. Journal of Substance Abuse Treatment, 10, 53-57.

Lima, M. S., Soares, B. O. S., Reisser, A. A. P. y Farrell, M. (2002). Pharmacological treatment of cocaine dependence: a systematic review. Addiction, 97, 931949.

Meyer, G. H. y Archer, R. P. (2001). The hard science of Rorschach research: what do we know and where do we go? Psychological Assessment, 13, 486-502. 
Nascimento, R. S. G. F. (2002). Estudo normativo do Rorschach para a cidade de São Paulo. Psico-USF, 7, 127-141.

Ochoa, E. (2000). Cocaína y comorbidad psiquiatrica. Actas Españolas de Psiquiatria, 28, 40-52.

Pinheiro, R. T., Sousa, P. L. R., Silva, R. A., Horta, B. L., Souza, R. M. y Fleming, M. (2001). Cocaine addicts and their families: an empirical study of the process of identification. International Journal of Psychoanalysis, 82, 347-360.

Verheul, R. y van den Brink, W. (2000). The role of personality pathology in the aetiology and treatment of substance use disorders. Current Opinion in Psychiatry, 13, 163169.

Vincent, K.R. y Harman, M.J (1991). The Exner Rorschach: an analysis of its clinical validity. Journal of Clinical Psychology, 47, 596-599.

Zillberman, M., Tavares, H., Blume, S. B. y el-Guebaly, N. (2003). Substance use disorders: sex differences and psychiatric comorbidities. Canadian Journal of Psychiatry, 48, 5-15. 